\title{
Feedback effects of estradiol and progesterone on ovulation and fertility of dairy cows after gonadotropin-releasing hormone-induced release of luteinizing hormone ${ }^{1}$
}

\author{
J. S. Stevenson ${ }^{2}$ and S. L. Pulley \\ Department of Animal Sciences and Industry, Kansas State University, Manhattan 66506-0201
}

\begin{abstract}
An experiment was conducted with the objective to determine the effects of estradiol, progesterone, presence of a corpus luteum (CL), and size of a dominant follicle on the characteristics and patterns of GnRHinduced LH release and subsequent ovulation during a timed artificial insemination (TAI) program, or a combination of these. In 70 lactating dairy cows, a total of 163 blood collection periods resulting in a GnRHinduced LH release were analyzed. Concentrations of LH were measured in hourly samples $(0$ through $6 \mathrm{~h}$ after $\mathrm{GnRH}$ ) during each of the blood collection periods, whereas concentrations of progesterone and estradiol were measured in the sample before $\mathrm{GnRH}$ treatment $(0 \mathrm{~h})$. Measures of LH included time to LH peak concentration during the 6 - $h$ blood collection period, the 2 largest concentrations of $\mathrm{LH}$, mean, and variance of the 6 LH concentrations under each LH curve. Individual and combination effects of CL presence and a dominant follicle $\leq$ or $>13.5 \mathrm{~mm}$, in addition to individual and combination effects of progesterone: low $(<0.45 \mathrm{ng} / \mathrm{mL}$; $\mathrm{n}=83)$, medium (0.53 to $2.41 \mathrm{ng} / \mathrm{mL} ; \mathrm{n}=25)$, and high ( 2.66 to $10.7 \mathrm{ng} / \mathrm{mL} ; \mathrm{n}=55)$, and estradiol: low $(<4.0 \mathrm{pg} / \mathrm{mL} ; \mathrm{n}=89)$ and high $(\geq 4.0 \mathrm{pg} / \mathrm{mL} ; \mathrm{n}=$ 74) were independent variables in models to determine their influence on characteristics of $\mathrm{LH}$ and ovulation. Injections of GnRH induced LH release during $6 \mathrm{~h}$ after each of 163 injections. Measures of GnRH-induced LH concentration were inhibited at greater concentrations of progesterone and in the presence of a CL. In contrast, GnRH-induced LH concentrations were increased when estradiol was $\geq 4.0 \mathrm{pg} / \mathrm{mL}$, but relatively unaffected by the size of the dominant follicle. Furthermore, resulting incidences of ovulation were decreased at

Received July 9, 2015.

Accepted January 10, 2016.

${ }^{1}$ Contribution number 15-433-J from the Kansas Agricultural Experiment Station, Manhattan 66506.

${ }^{2}$ Corresponding author: jss@ksu.edu

${ }^{3}$ Current address: College of Agriculture and Technology, Arkansas State University, Jonesboro.
\end{abstract}

greater progesterone concentrations and presence of a $\mathrm{CL}$, and increased at greater estradiol concentrations and presence of follicles $>13.5 \mathrm{~mm}$. In cows with or without a CL, the presence of a follicle $>13.5 \mathrm{~mm}$ did not increase mean LH concentration or incidence of ovulation. We conclude that when progesterone concentration exceeded $0.5 \mathrm{ng} / \mathrm{mL}$ at the time of $\mathrm{GnRH}$ treatment, subsequent LH concentrations and ovulation were suppressed. At that same concentration of progesterone or when concentrations of estradiol were $\geq 4 \mathrm{pg} / \mathrm{mL}$, TAI pregnancy outcomes were improved in the face of similar incidences of ovulation suggesting greater progesterone or lesser estradiol at the time of AI may inhibit pregnancy establishment by other mechanisms.

Key words: estradiol, gonadotropin-releasing hormone-induced luteinizing hormone release, ovulation, progesterone

\section{INTRODUCTION}

Controlling follicular development and corpus luteum (CL) function are essential components of timed AI (TAI) programs. Superior ovulatory responses to GnRH to start and end the traditional Ovsynch TAI program [GnRH-7 d- PGF $_{2 \alpha}-48$ to $72 \mathrm{~h}-\mathrm{GnRH}-\mathrm{TAI} 72$ $\mathrm{h}$ after $\left.\mathrm{PGF}_{2 \alpha}\right]$ facilitate acceptable pregnancy per AI (P/AI; Pursley et al., 1997; Stevenson et al., 2012; Bisinotto et al., 2015). Few studies have reported concentrations of LH after GnRH in lactating dairy cows (Lucy and Stevenson, 1986; Souza et al., 2009) and none associated with the sequence of $\mathrm{GnRH}$ treatments in a TAI program. A recent study of 24 cows evaluated the effect of progesterone concentration on $\mathrm{GnRH}$-induced LH release in a TAI setting (Giordano et al., 2012), but insufficient numbers of observations prevented any conclusions regarding the effects of GnRH-induced LH release on ovulation success in the face of the authors' defined low and high progesterone concentrations. Furthermore, the effects of estradiol on LH release in that study were not examined in its relationship to facilitating LH release and subsequent ovulation. The 
relationship of LH release to $\mathrm{GnRH}$, subsequent ovulation, and concentrations of estradiol and progesterone of milked cows subjected to TAI programs has not been documented.

The importance of further understanding of these relationships is critical to enhancing the success of TAI programs. In the absence of any presynchronization treatment, synchronization of follicle growth by inducing ovulation in response to the first $\mathrm{GnRH}$ treatment of the TAI program occurs in only 45 to $50 \%$ of dairy cows (Pursley et al., 1995; Moreira et al., 2000). In addition, approximately 50 to $66 \%$ of dairy cows (Pursley et al., 1995; Vasconcelos et al., 1999) in various stages of the estrous cycle ovulate in response to $\mathrm{GnRH}$. Ovulation (Stevenson et al., 2008) and GnRH-induced LH release are suppressed in the presence of a CL and at larger concentrations of progesterone in dairy cattle (Giordano et al., 2012; Pulley et al., 2015).

A second limitation to success of TAI programs is the inability of a single dose of $\mathrm{PGF}_{2 \alpha}$ to induce complete $\mathrm{CL}$ regression. To achieve high $\mathrm{P} / \mathrm{AI}$, concentrations of progesterone on the day of TAI must be relatively low $(<0.4 \mathrm{ng} / \mathrm{mL})$ in lactating dairy cows (Santos et al., 2010; Wiltbank et al., 2014). Administering $\mathrm{PGF}_{2 \alpha}$ as a single dose on $\mathrm{d} 7$ or as 2 doses on $\mathrm{d} 5$ and 6 after GnRH usually results in only 70 to $84 \%$ of cows with progesterone $<0.3 \mathrm{ng} / \mathrm{mL}$ on the day of the TAI (Santos et al., 2010), and likely influences the characteristics of GnRH-induced LH release when progesterone concentrations are at or near baseline at the final GnRH treatment and subsequent P/AI.

A third limitation is the inability to synchronize ovulation between 24 and $32 \mathrm{~h}$ after the final $\mathrm{GnRH}$ treatment (Pursley et al., 1995). Synchronized ovulation averages $85 \%$ in dairy cows (Santos et al., 2010), and this percentage seems to decrease when cows are exposed to heat stress because of the supposed deleterious effects of hyperthermia on ovulation (López-Gatius et al., 2005). Of the 3 identified limitations, 2 are related to the success of ovulation, which is dependent on $\mathrm{GnRH}$-induced LH release and its in vivo pre-GnRH steroid milieu.

Progesterone and estradiol regulate LH secretion from the anterior pituitary in ruminants (Goodman and Karsch, 1980; Schoenemann et al., 1985; Nett et al., 2002). Steroids modulate LH release through indirect mechanisms that regulate hypothalamic $\mathrm{GnRH}$ secretion or directly on the pituitary by enhancing or suppressing pituitary response to GnRH (Schoenemann et al., 1985; Baratta et al., 1994; Rispoli and Nett, 2005). Increase in estradiol secretion by the preovulatory follicle during the preovulatory period increases the sensitivity of the anterior pituitary to GnRH by upregulating $\mathrm{GnRH}$ receptor mRNA in gonadotrophs
(Schoenemann et al., 1985). In addition, estradiol enhances hypothalamic GnRH secretion, eventually leading to the preovulatory GnRH surge, which subsequently initiates the LH surge. In contrast, in the presence of a functional CL, progesterone seems to block the stimulatory effects of estradiol at the hypothalamus (Schoenemann et al., 1985; Girmus and Wise, 1992) and possibly at the anterior pituitary (Baratta et al., 1994; Rispoli and Nett, 2005).

Because ovulation is solely dependent on spontaneous or exogenous GnRH-induced LH release, which is a key component of successful TAI programs, we hypothesized that concentrations of estradiol and progesterone likely facilitate or inhibit GnRH-induced LH release, respectively. Therefore, the objective of the present investigation was to determine the effects of the presence of a CL, dominant follicle, and acute effects of varying concentrations of progesterone and estradiol on GnRHinduced LH release and ovulatory responses in lactating cows subjected to a TAI program before first AI.

\section{MATERIALS AND METHODS}

The data for the present study came from our recently published (Pulley et al., 2015) report that was designed to determine the incidence of spontaneous and predictable $\mathrm{GnRH}$-induced LH surges and subsequent ovulation in lactating dairy cows enrolled in a TAI program preceded by the presynchronization of estrous cycles. Ancillary measures of progesterone, estradiol, and ovarian structures also were made to confirm our previous findings in response to the same 2 treatments (Stevenson et al., 2012) as well as improved P/AI in a previous large 4-herd study (Stevenson and Pulley, 2012). The purpose of the present investigation was to examine in more detail the relationships of estradiol and progesterone to $\mathrm{GnRH}$-induced $\mathrm{LH}$ release and subsequent ovulation.

\section{Cows, Housing, and Diets}

The previous study from which these data were derived was approved by the Kansas State University Institutional Animal Care and Use Committee. Seventy lactating Holstein cows were enrolled at calving from September 2011 through March 2012 at the Kansas State University Dairy Teaching and Research Center. First-lactation cows $(\mathrm{n}=45)$ averaged $42.4 \pm 0.5 \mathrm{~kg}$ of ECM per day $(61.3 \pm 0.8 \mathrm{DIM})$ and 25 multiplelactation cows averaged $51.5 \pm 1.3 \mathrm{~kg}$ per day $(60.7$ $\pm 1.1 \mathrm{DIM})$. Cows were considered to be healthy and housed individually in a tie-stall barn equipped with individual feed boxes, automatic water basins, and stall mats covered with wood shavings. Cows were moved to 
a double-6 Herringbone parlor and milked thrice daily. Cows were fed individually twice daily at 0630 and $1600 \mathrm{~h}$. A total mixed diet calculated to meet nutrient requirements for lactating dairy cows producing $50 \mathrm{~kg}$ of 3.5\% milk (NRC, 2001) consisted of alfalfa hay, corn silage, soybean meal, whole cottonseed, corn or milo grain, corn gluten feed, vitamins, and minerals. Cows were evaluated daily for health status by trained farm personnel.

\section{Experimental Design, Blood Sampling, and Radioimmunoassays}

Cows were stratified by lactation number and assigned randomly to 2 presynchronization-TAI programs (Figure 1). One group of 33 cows were treated with 100- $\mu \mathrm{g}$ GnRH (Pre-GnRH; $2 \mathrm{~mL}$ Factrel; Zoetis, Florham Park, NJ) administered $3 \mathrm{~d}$ after treatment with PGF $_{2 \alpha}$ (Pre-PG; $5 \mathrm{~mL}$ of Lutalyse Sterile Solution, Zoetis), whereas 37 cows were not treated with $\mathrm{GnRH}$, but received 2 treatments of $\mathrm{PGF}_{2 \alpha}$ (PG-1 and PG-2). Ten days after Pre-PG or PG-2, all cows were subjected to the Ovsynch program $(100 \mu \mathrm{g}$ of GnRH administered $7 \mathrm{~d}$ before and either 56 or $72 \mathrm{~h}$ after $\mathrm{PGF}_{2 \alpha}$; TAI at $72 \mathrm{~h}$ after $\left.\mathrm{PGF}_{2 \alpha}\right)$. Body condition scores were assigned to cows $7 \mathrm{~d}$ before GnRH-1 (Figure 1). Blood samples were collected before each GnRH treatment and hourly for $6 \mathrm{~h}$ (Pulley et al., 2015). Of 173 6-h blood collection periods in which $\mathrm{GnRH}$ was injected at $0 \mathrm{~h}$ (Figure 1), only 163 resulted in a GnRH-induced LH pattern. Data from 10 collection periods were dropped from the analyses because spontaneous LH surges occurred before $\mathrm{GnRH}$ was injected.

Blood sera concentrations of LH collected during each 6 -h collection window were measured in triplicate $(100 \mu \mathrm{L})$ in 6 assays by liquid-phase double-antibody RIA (Atkins et al., 2008). Pooled bovine sera assayed in quadruplicate at $25,40,60,100,175,200$, and $300 \mu \mathrm{L}$ averaged $9.8 \pm 0.3 \mathrm{ng} / \mathrm{mL}$ and paralleled the standard curve. Intra- and interassay CV averaged 4.9 and $5.7 \%$, respectively.

Concentrations of progesterone in blood serum were measured in samples collected before each GnRH treatment (Figure 1). All sera samples for progesterone concentration were measured in duplicate and analyzed by direct quantitative (nonextracted) RIA using Coat-A-Count progesterone kits (catalog no. TKPG; Siemens Medical Solutions Diagnostics, Los Angeles, CA) previously validated for bovine serum (Stevenson et al., 2012). Assay sensitivity of the progesterone RIA was $4.7 \pm 0.4 \mathrm{pg} / \mathrm{mL}$, and intra- and inter-assay CV for 2 assays were 3.5 and $5.2 \%$, respectively, for a pool of bovine serum that averaged $2.8 \pm 0.04 \mathrm{ng} / \mathrm{mL}$.
Concentrations of estradiol-17 $\beta$ were measured in triplicate in 1 RIA in blood samples collected before each GnRH treatment (Stevenson et al., 2008; Figure 1). Assay sensitivity averaged $0.11 \pm 0.04 \mathrm{pg}$ per tube, and the intraassay $\mathrm{CV}$ averaged $5.3 \%$. Addition of known amounts of estradiol $(1.71,5.12$, and $10.24 \mathrm{pg} /$ $\mathrm{mL})$ were recovered $\left(\mathrm{R}^{2}=0.995\right)$ and paralleled the standard curve.

\section{Ovarian Structures and Ovulation}

Transrectal ovarian scans were conducted in all cows by ultrasonography $(7.5-\mathrm{MHz}$ linear-array transducer, Aloka 500V; Corometrics Medical Systems Inc., Wallingford, CT) to record diameter and map location of follicles $\geq 5 \mathrm{~mm}$ and any CL present at Pre-GnRH, GnRH-1, and GnRH-2 (Figure 1). Additional scans were made 3 to $7 \mathrm{~d}$ after each $\mathrm{GnRH}$ treatment including scans made before each $\mathrm{PGF}_{2 \alpha}$ injection (PG-2, Pre-PG, and PG-2; Figure 1). A map of each ovary was drawn with the position and size of all follicles and location of each CL, which allowed for evaluation of subsequent ovulatory responses and determination of the dominant follicle. Dominant follicles were determined by tracing back from ovulation on previously recorded sonograms. When ovulation did not occur, the largest follicle recorded at the previous scan was assumed the

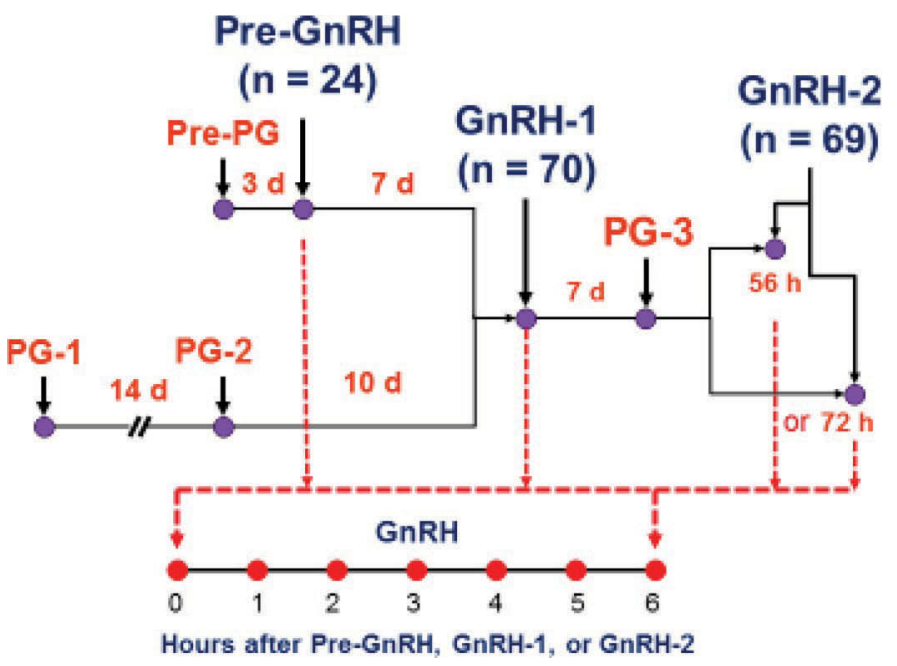

Figure 1. Design of hourly blood collection after $100 \mu \mathrm{g}$ of GnRH in dairy cows. Twenty-four cows received the Pre-GnRH treatment (43 to $67 \mathrm{DIM}$ ), 70 cows received GnRH at GnRH-1 (46 to $74 \mathrm{DIM}$ ), and 69 cows received GnRH-2 (55 to 83 DIM). Only cows with LH release patterns clearly initiated by $\mathrm{GnRH}$ ( $\mathrm{LH}$ peaks at 1 or $2 \mathrm{~h}$ after $\mathrm{GnRH})$ during the 6 -h blood collection periods were analyzed. Concentrations of estradiol and progesterone were quantified in the 0 -h samples just before $\mathrm{GnRH}$ was injected. Numbers in parentheses represent the number of blood collection periods after $\mathrm{GnRH}$ at each injection. Color version available online. 
dominant follicle. In some cases, the largest follicle may not have been the dominant follicle, but with relatively high incidence of ovulation and frequency of ovarian scans, few errors were made in identifying the dominant follicle. Pregnancy was diagnosed by transrectal ultrasonography at d 31 and 61 after TAI.

\section{Definitions of Hormonal Responses and Categories}

Various characteristics of each GnRH-induced LH pattern were created. Time to LH peak concentration during the 6 -h blood collection period and the 2 largest LH concentrations, overall mean and variance of the 6 LH concentrations were calculated. Characteristics of LH patterns and area under each LH curve were calculated by the trapezoid method as described previously (Pulley et al., 2015).

Effect of dominant follicle diameter and presence of a luteal structure on GnRH-induced LH concentrations was determined. The median diameter of dominant follicles $(13.5 \mathrm{~mm})$ was used as the cut point. Observations representing cows with a dominant follicle $\leq 13.5$ $\mathrm{mm}(\mathrm{n}=83)$ were compared with those having a dominant follicle $>13.5 \mathrm{~mm}(\mathrm{n}=80)$. Presence $(\mathrm{n}=86)$ or absence $(\mathrm{n}=77)$ of at least $1 \mathrm{CL}$ was determined before each GnRH treatment.

To determine the effect of steroid concentrations on GnRH-induced LH release and its characteristics, estradiol and progesterone were measured in the $0-\mathrm{h}$ sample that was collected just before each GnRH treatment. Three concentration ranges of progesterone were created: low $(<0.45 \mathrm{ng} / \mathrm{mL} ; \mathrm{n}=83)$, medium [0.53 to $2.41 \mathrm{ng} / \mathrm{mL} ; \mathrm{n}=25$ (17 of $25>1 \mathrm{ng} / \mathrm{mL})]$, and high [2.66 to $10.7 \mathrm{ng} / \mathrm{mL} ; \mathrm{n}=55$ (47 of $55>3 \mathrm{ng} / \mathrm{mL}$ )]. These categories were chosen to simulate concentrations of progesterone consistent with estrus, metestrus, and diestrus, respectively. In a similar manner, the median estradiol concentration was used as the cut point: low $(<4.0 \mathrm{pg} / \mathrm{mL} ; \mathrm{n}=89)$ and high $(\geq 4.0 \mathrm{pg} / \mathrm{mL} ; \mathrm{n}=74)$ to simulate concentrations of estradiol consistent with stages other than estrus and estrus, respectively.

\section{Statistical Analyses}

Normality of the LH characteristics (2 largest LH concentrations, area under the LH curve, mean, and variance of the 6 hourly LH concentrations, and time to peak LH) of each LH profile after GnRH was tested. All characteristics had unequal variances except for time to LH peak. Several transformations of the data failed to resolve the problem of heterogeneous variance. Alternatively, the MIXED procedure (version 9.4, Statistical Analysis System Inc., Cary, NC) has the ability to adjust for unequal variances. The REPEATED option added after the model statement, with GROUP = category (3 progesterone, 2 estradiol categories, presence or absence of a CL, or dominant follicle $\leq 13.5$ or $>13.5$ $\mathrm{mm}$ ), allowed for estimating the individual categorical variances. Furthermore, including the option, DDFM = SATTERTHWAITE, to the MODEL statement adjusted the degrees of freedom for unequal variances. Each MIXED model contained the fixed effects of category (see below), lactation number (1 vs. $2+)$, BCS $(<2.75$ vs. $\geq 2.75$ ), and Dairy Herd Improvement test-day ECM yield nearest the time of GnRH treatment, and DIM at GnRH treatment as covariables. In 6 separate models, the categories included (1) progesterone (3 concentration ranges), (2) estradiol (2 concentration ranges), (3) combination (main effects and interaction) of the preceding 2 categories, (4) presence or absence of a CL, (5) dominant follicle diameter $(\leq 13.5$ or $>13.5 \mathrm{~mm})$, and (6) combination (main effects and interaction) of the preceding 2 categories. Least squares means were separated by the Tukey procedure for progesterone, or by $F$-test for estradiol, presence of CL, or dominant follicle size.

Profiles of LH patterns during $6 \mathrm{~h}$ after GnRH treatment were analyzed in the MIXED procedure using the REML option. The model consisted of cow nested within progesterone, estradiol, CL, or follicle category, treated as a random variable (split-plot error), and the fixed effects of progesterone $(\mathrm{n}=3)$ or estradiol $(\mathrm{n}=2)$ category or their combination, time, category $\times$ time interaction, lactation number (1 vs. $2+$ ), BCS (described previously), and ECM and DIM at GnRH treatment as covariables. Days in milk were included to adjust for potential differences in $\mathrm{GnRH}$-induced $\mathrm{LH}$ release that could be attributable to stage of lactation even though all injections occurred during a time span of $24 \mathrm{~d}$.

Other models replaced the category of steroid concentrations or their combination with the fixed effects of CL (0 vs. 1$)$, diameter of the dominant follicle $(\leq 13.5$ vs. $>13.5 \mathrm{~mm}$ ), or their combination. All category effects were tested by the split-plot error variance. Least squares means within hour were separated by $t$-test when a protected $F$-test was detected (minimum of $P$ $<0.01)$.

Peak LH concentrations after GnRH were regressed on either progesterone or estradiol concentrations measured in the 0-h sample before each GnRH treatment. Resulting linear regression equations and $R^{2}$ values were calculated in Excel 2010 (Microsoft Corp., Redmond, WA). In addition, to better understand the relationship among estradiol, progesterone, and GnRHinduced peak LH concentration with subsequent ovulation response, multivariable logistic regression models using procedure LOGISTIC in SAS were developed to 
regress the predicted probability of ovulation on peak LH concentration after GnRH, after adjusting for the concentrations of estradiol or progesterone at the time of $\mathrm{GnRH}$ treatment.

To detect any interactions of combinations of estradiol $(<4.0$ vs. $\geq 4.0 \mathrm{pg} / \mathrm{mL})$ and progesterone $(<0.4$ vs. $>0.53 \mathrm{ng} / \mathrm{mL}$ ) or combinations of CL and follicle, mean concentrations of $\mathrm{LH}$ during the GnRH-induced LH profile and incidence of ovulation were analyzed in the MIXED procedure (as described for previous variables to correct for heterogeneity) with fixed effects of hormonal or ovarian structure combination (n $=4$ ), lactation number, BCS, and ECM and DIM at GnRH treatment as covariables. Least squares means were separated by the Tukey procedure. We combined the 2 largest progesterone categories into 1 category for these analyses because in a previous report (Giordano et al., 2012), the authors included cows in their high progesterone group that had concentrations of progesterone ranging from 1.1 to $5.3 \mathrm{ng} / \mathrm{mL}$. Furthermore, the average concentration of the 2 largest progesterone categories $(>0.53 \mathrm{ng} / \mathrm{mL})$ in the present study was 2.0 $\pm 0.2 \mathrm{ng} / \mathrm{mL}$, and in 70 of the 80 blood collection periods represented therein, progesterone exceeded $1 \mathrm{ng} /$ $\mathrm{mL}$.

Multivariate ANOVA also was applied to all characteristics of LH in the GLM procedure of SAS to determine partial correlation coefficients. Each of 2 models contained the fixed effects of lactation number (1 vs. $2+$ ), BCS ( $<2.75$ vs. $\geq 2.75$ ), progesterone or estradiol category (described previously), and ECM and DIM at GnRH treatment as covariables.

Because $\mathrm{P} / \mathrm{AI}$ was zero in some tested categories, the GLIMMIX procedure (METHOD = LAPLACE; ILINK $=$ LOGIT DIST $=$ BINOMIAL SOLUTION ODDSRATIO) did not converge or the Pearson chisquare/df was $<0.9$, thus producing erroneous $F$-tests and least squares means when assessing $\mathrm{P} / \mathrm{AI}$ in 66 cows after TAI. Therefore, procedure MIXED was employed to generate appropriate $F$-tests. The model included the independent effects of estradiol ( $<4.0$ vs. $\geq 4.0 \mathrm{pg} / \mathrm{mL}$ ), progesterone ( $<0.45$ vs. $>0.53 \mathrm{ng} / \mathrm{mL}$ ), their interaction, lactation number (1 vs. $2+$ ), BCS, and ECM and DIM as covariables to assess their effects on $\mathrm{P} / \mathrm{AI}$ and ovulation incidence after GnRH-2 (Figure 1). Reported means for these measures of $\mathrm{P} / \mathrm{AI}$ were the raw unadjusted percentages.

\section{RESULTS}

By design, cows were uniform in DIM, and neither ECM yield ( $P$-values ranged from 0.28 to 0.97 ) nor BCS ( $P$-values ranged from 0.26 to 0.98 ) significantly influenced characteristics of LH release or ovulation oc- currence. Therefore, the 163 GnRH-induced LH profiles that were characterized during a 24-d period, of which 139 occurred during a 17-d period, were combined for analyses. Several of the LH characteristics were different between first- and multiple-lactation cows, in which concentration of $\mathrm{LH}$ was consistently greater in firstlactation cows. In no case did $\mathrm{GnRH}$ fail to induce $\mathrm{LH}$ release during $6 \mathrm{~h}$ after each injection.

\section{Presence of a Corpus Luteum and Progesterone}

The GnRH-induced LH release pattern was suppressed $(P<0.001)$ in cows bearing at least $1 \mathrm{CL}$ compared with no CL at GnRH treatment (upper panel in Figure 2). Every LH characteristic assessed resulting from the individual GnRH-induced LH profiles was suppressed $(P \leq 0.05)$ in cows bearing at least $1 \mathrm{CL}$ compared with those without visible CL at GnRH treatment (Table 1). Furthermore, progesterone concentration, as expected, was less $(P<0.05)$ in no CL than CL-bearing cows, but the diameter of the dominant follicle and concentration of estradiol did not differ between no CL and CL-bearing cows (Table 1). Ovulation response to GnRH was suppressed in cows with CL compared with no CL (Table 1).

To evaluate the effect of the CL on GnRH-induced LH release, concentrations of progesterone were examined and differed $(P<0.05)$ among the 3 concentration categories (Table 1). Profiles of GnRH-induced LH concentrations were inversely related to concentrations of progesterone in a dose-dependent manner (bottom panel; Figure 2). Significant $(P<0.001)$ effects of progesterone concentration, time, and progesterone concentration category $\times$ time influenced LH concentration. Low concentrations of progesterone consistent with cows in estrus were least suppressive to GnRHinduced LH release compared with medium and high concentrations at 1 through $4 \mathrm{~h}$ after $\mathrm{GnRH}$, whereas differences between lowest and greatest progesterone concentration category persisted through $5 \mathrm{~h}$ after GnRH (bottom panel; Figure 2).

Concentrations of progesterone and the second largest $\mathrm{LH}$ concentration during $56 \mathrm{~h}$ after $\mathrm{GnRH}$ differed $(P<0.001)$ among the 3 progesterone categories (Table 1). All other measures of $\mathrm{LH}$ after $\mathrm{GnRH}$, except time to LH peak, in cows with the lowest progesterone concentration differed $(P<0.001)$ from cows with medium and high concentrations of progesterone (Table 1). Time to LH peak concentration was greater at low and medium concentrations of progesterone compared with high concentration (Table 1). Ovulation response to GnRH-induced LH release was suppressed at high concentrations of progesterone compared with low and medium concentrations (Table 1). 

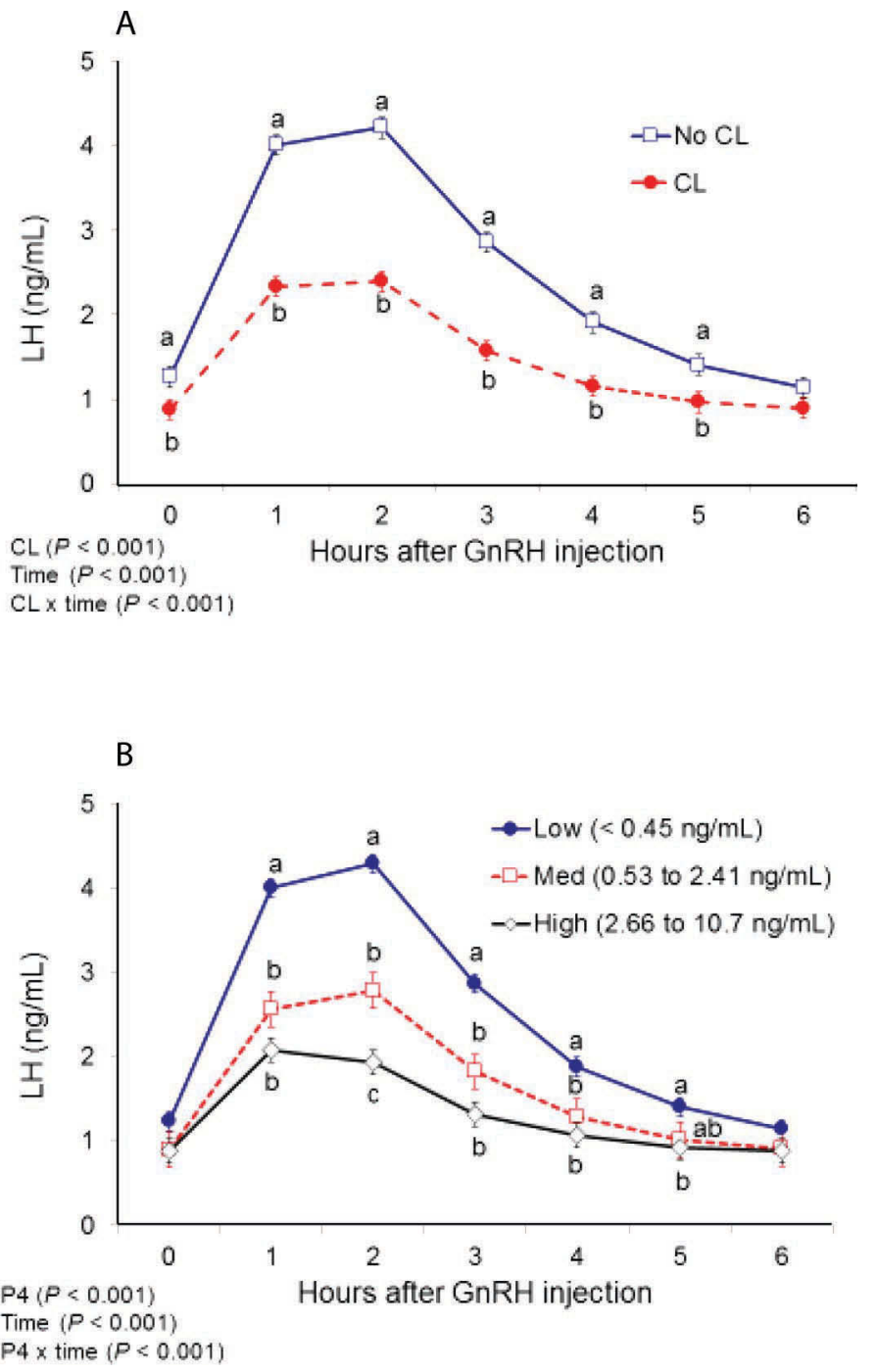

Figure 2. (A) Least squares means LH concentrations based on the presence $(\mathrm{n}=77)$ or absence $(\mathrm{n}=86)$ of a corpus luteum $(\mathrm{CL})$ at the time of $\mathrm{GnRH}$ treatment. (B) Least squares means LH concentrations during $6 \mathrm{~h}$ after $100 \mu \mathrm{g}$ of GnRH for dairy cows having low $(\mathrm{n}=83)$, medium $(\mathrm{n}=25)$, or high $(\mathrm{n}=55)$ concentrations of progesterone (P4) at the time of GnRH treatment. Means with different letters $(\mathrm{a}-\mathrm{c})$ within hour differ $(P \leq 0.05)$; bars associated with each mean represent the standard errors. Color version available online.

The overall relationship between peak LH concentration during the 6 -h profile and progesterone concentrations was negative and linear (Figure 3A). Visual incidence of ovulation seemed to be distributed across the range of progesterone concentrations, but was greater when peak LH concentrations were greater and progesterone concentrations were low. A multivariable logistic regression model including progesterone concentration before GnRH treatment produced a predicted probability of ovulation regressed on $\mathrm{GnRH}$-induced peak $\mathrm{LH}$ concentration with no evidence of lack of fit $(P=0.62$;
Figure 3B). The model parameters of the predicted probability of ovulation $(\mathrm{y})$ were $\mathrm{y}=1.17+0.26 \times \mathrm{LH}$ peak concentration $(P=0.07)-0.35 \times$ progesterone concentration $(P<0.001)$ before GnRH treatment produced odds ratios $(\mathbf{O R})$ for $\mathrm{LH}(\mathrm{OR}=1.29 ; 95 \% \mathrm{CI}$ $=0.98$ to 1.72$)$ and for progesterone $(\mathrm{OR}=0.73 ; 95 \%$ $\mathrm{CI}=0.59$ to 0.84 ). The coefficient for progesterone was negative indicating that at greater concentrations of peak LH, ovulation was inhibited.

Almost all LH characteristics in the GnRH-induced LH profiles were correlated with ovulation (data not shown), but the largest partial correlations $(P<0.01)$ in the range of 0.23 to 0.26 were for the overall and second largest LH concentration during the 6-h GnRHinduced LH profile.

\section{Presence of a Dominant Follicle and Estradiol}

Concentrations of $\mathrm{LH}$ after $\mathrm{GnRH}$ treatment were not affected by size of the dominant follicle (upper panel; Figure 4). Only the concentrations of LH and estradiol before $\mathrm{GnRH}$ treatment tended $(P<0.10)$ to differ between follicle size categories, with the tendency for more LH release and greater estradiol in larger follicles (Table 2). In contrast, release of $\mathrm{LH}$ in response to GnRH was affected by concentration of estradiol $(P$ $<0.001)$ in a dose-dependent manner, and time $(P<$ $0.001)$, and their interaction $(P<0.001$; bottom panel in Figure 4). Ovulation incidence was greater $(P<$ 0.05 ) in cows with follicles $>13.5 \mathrm{~mm}$ (Table 2).

Concentrations of LH were related positively to increased concentrations of estradiol (Table 2). All measures of GnRH-induced LH release were greater in cows with concentrations of estradiol were $\geq 4.0 \mathrm{pg} /$ $\mathrm{mL}$, except the LH concentration before GnRH treatment, which tended $(P<0.10)$ to be greater than in cows with lesser concentrations of estradiol (Table 2). Mean follicle diameter tended $(P<0.10)$ to be greater, whereas progesterone was less $(P<0.05)$ at greater concentrations of estradiol. Incidence of ovulation also was greater $(P<0.05)$ at greater concentrations of estradiol (Table 2). Ovulation incidence was greater $(P$ $<0.05$ ) in cows with estradiol $\geq 4 \mathrm{pg} / \mathrm{mL}$ (Table 2). Regression of peak LH concentrations during the 6-h period on concentrations of estradiol was positive and linear (Figure 3C).

A multivariable logistic regression model including estradiol concentration before GnRH treatment produced a predicted probability of ovulation regressed on GnRH-induced peak LH concentration with no evidence of lack of fit $(P=0.51$; Figure 3D). The model parameters of the predicted probability of ovulation (y) were $\mathrm{y}=-1.84+0.47 \times \mathrm{LH}$ peak concentration $(P$ 
$=0.002)+0.39 \times$ estradiol concentration $(P=0.04)$ before $\mathrm{GnRH}$ treatment produced $\mathrm{OR}$ for $\mathrm{LH}(\mathrm{OR}=$ $1.59 ; 95 \% \mathrm{CI}=1.18$ to 2.16 ) and for estradiol (OR $=$ 1.47; $95 \% \mathrm{CI}=1.01$ to 2.14 ). The coefficient for estradiol was positive, indicating that at greater concentrations of peak LH, ovulation was stimulated.

No interactions were detected between size of the dominant follicle and presence of the CL except for a tendency $(P=0.064)$ for differences in mean concentrations of estradiol. For cows with a CL, concentrations of estradiol were greater when follicles were $>13.5 \mathrm{~mm}$ $(4.1 \pm 0.2 \mathrm{pg} / \mathrm{mL})$ than when follicles were $\leq 13.5 \mathrm{~mm}$ $(3.4 \pm 0.1 \mathrm{pg} / \mathrm{mL})$. In contrast, in the absence of a CL, concentrations of estradiol did not differ between larger and smaller follicles $(4.5 \pm 0.2$ vs. $4.4 \pm 0.1 \mathrm{pg} / \mathrm{mL})$, respectively.

Although concentrations of $\mathrm{LH}$ during $6 \mathrm{~h}$ after GnRH were less in the presence of a CL (Table 1), a tendency $(P=0.091)$ was detected for LH to be less in cows having smaller than larger follicles in the presence of a CL, but not in its absence (Table 3). Incidence of ovulation (Table 3$)$ also was less $(P=0.022)$ in the presence of smaller than larger follicles (main effect means $=64.8$ vs. $82.9 \%)$ and less $(P=0.001)$ in the presence of a CL (main effect means $=60.5$ vs. $88.4 \%$ ).

No interactions were detected for the effects of both steroids on mean GnRH-induced LH concentrations during $6 \mathrm{~h}$ after GnRH (Figure 5). Mean concentrations of LH were consistently greater after $\mathrm{GnRH}$ when estradiol $\geq 4 \mathrm{pg} / \mathrm{mL}$ than when estradiol was $<4 \mathrm{pg} /$ $\mathrm{mL}$, regardless of concentration of progesterone. The GnRH-induced LH release, however, was smaller in cows with high versus low concentrations of progesterone before GnRH treatment (Figure 5).

\section{Pregnancy Outcome}

Of the 70 cows receiving the TAI, 66 were presented for pregnancy diagnosis, and 31 cows $(46.9 \%)$ were pregnant at d 31 and 30 cows $(45.4 \%)$ at d 61, with 1 intervening pregnancy loss. Three cows were culled before the d 31 pregnancy diagnosis and 1 cow had a spontaneous LH surge before $\mathrm{GnRH}$ treatment. More $(P=0.02)$ cows with progesterone $<0.45 \mathrm{ng} / \mathrm{mL}$ conceived compared with none with progesterone $>0.53$ $\mathrm{ng} / \mathrm{mL}$, in the face of similar $(P=0.68)$ ovulation incidences (91.5 vs. $85.7 \%$ ), respectively (Figure 6). Furthermore, when estradiol was $\geq 4 \mathrm{pg} / \mathrm{mL}$ at either 56 or $72 \mathrm{~h}$ after $\mathrm{PGF}_{2 \alpha}$, more $(P=0.05)$ cows conceived than when estradiol was $<4 \mathrm{pg} / \mathrm{mL}$, in the face of similar $(P=0.12)$ ovulation incidences, respectively (Figure $6)$. Interactions between the progesterone and estradiol categories were not significant for $\mathrm{P} / \mathrm{AI}(P=0.46)$ or for ovulation incidence $(P=0.17)$.

\section{DISCUSSION}

The current experiment evaluated the acute effects of ovarian structures and steroid concentrations on GnRH-induced LH release and incidence of ovulation in lactating dairy cows enrolled in a TAI program before first service. The study included periods in which cows were in diestrus (functional CL, moderate to high concentrations of progesterone and low concentrations of estradiol) as well as during postluteal regression (proestrus or estrus) when progesterone was low and estradiol was high. Novel to this report are the combined effects of estradiol, progesterone, follicle size, and luteal status as they are shown to modulate the magnitude

Table 1. Presence of a corpus luteum (CL) and concentrations of progesterone alter LH characteristics during $6 \mathrm{~h}$ after GnRH treatment and subsequent $\mathrm{GnRH}$-induced ovulation in lactating dairy cows ${ }^{1}$

\begin{tabular}{|c|c|c|c|c|c|}
\hline \multirow[b]{2}{*}{ Item } & \multicolumn{2}{|c|}{ CL present } & \multicolumn{3}{|c|}{ Progesterone $^{2}(\mathrm{ng} / \mathrm{mL})$} \\
\hline & No & Yes & $<0.45$ & 0.53 to 2.41 & 2.66 to 10.70 \\
\hline Observations (no.) & 77 & 86 & 83 & 25 & 55 \\
\hline Pre-GnRH LH (ng/mL) & $1.3 \pm 0.1^{\mathrm{a}}$ & $0.9 \pm 0.03^{\mathrm{b}}$ & $1.3 \pm 0.1^{\mathrm{a}}$ & $0.9 \pm 0.05^{\mathrm{b}}$ & $0.9 \pm 0.04^{\mathrm{b}}$ \\
\hline Largest $\mathrm{LH}$ value $(\mathrm{ng} / \mathrm{mL})$ & $4.5 \pm 0.2^{\mathrm{a}}$ & $2.7 \pm 0.2^{\mathrm{b}}$ & $4.6 \pm 0.2^{\mathrm{a}}$ & $3.0 \pm 0.3^{\mathrm{b}}$ & $2.3 \pm 0.2^{\mathrm{b}}$ \\
\hline Second largest $\mathrm{LH}$ value $(\mathrm{ng} / \mathrm{mL})$ & $3.8 \pm 0.2^{\mathrm{a}}$ & $2.1 \pm 0.1^{\mathrm{b}}$ & $3.8 \pm 0.2^{\mathrm{a}}$ & $2.4 \pm 0.2^{\mathrm{b}}$ & $1.7 \pm 0.1^{\mathrm{c}}$ \\
\hline Area under the $\mathrm{LH}(\mathrm{ng} \cdot \mathrm{h} / \mathrm{mL})$ & $14.4 \pm 0.8^{\mathrm{a}}$ & $10.2 \pm 0.6^{\mathrm{b}}$ & $14.4 \pm 0.8^{\mathrm{a}}$ & $10.5 \pm 0.9^{\mathrm{b}}$ & $9.7 \pm 0.7^{\mathrm{b}}$ \\
\hline Mean LH (ng/mL) & $2.1 \pm 0.08^{\mathrm{a}}$ & $1.4 \pm 0.07^{\mathrm{b}}$ & $2.2 \pm 0.08^{\mathrm{a}}$ & $1.6 \pm 0.1^{\mathrm{b}}$ & $1.3 \pm 0.07^{\mathrm{b}}$ \\
\hline Variance LH & $2.5 \pm 0.3^{\mathrm{a}}$ & $0.7 \pm 0.2^{\mathrm{b}}$ & $2.6 \pm 0.3^{\mathrm{a}}$ & $1.0 \pm 0.3^{\mathrm{b}}$ & $0.4 \pm 0.2^{\mathrm{b}}$ \\
\hline Time to LH peak $(\mathrm{h})$ & $1.6 \pm 0.07^{\mathrm{a}}$ & $1.4 \pm 0.06^{\mathrm{b}}$ & $1.6 \pm 0.06^{\mathrm{a}}$ & $1.5 \pm 0.12^{\mathrm{a}}$ & $1.3 \pm 0.09^{\mathrm{b}}$ \\
\hline Follicle diameter (mm) & $13.8 \pm 0.4$ & $13.7 \pm 0.4$ & $13.6 \pm 0.4$ & $13.9 \pm 0.8$ & $13.8 \pm 0.4$ \\
\hline Estradiol $(\mathrm{pg} / \mathrm{mL})$ & $4.4 \pm 0.2$ & $3.8 \pm 0.1$ & $4.6 \pm 0.1^{\mathrm{a}}$ & $4.3 \pm 0.3^{\mathrm{a}}$ & $3.3 \pm 0.1^{\mathrm{b}}$ \\
\hline Progesterone (ng/mL) & $0.2 \pm 0.04^{\mathrm{a}}$ & $3.4 \pm 0.2^{\mathrm{b}}$ & $0.2 \pm 0.01^{\mathrm{a}}$ & $1.5 \pm 0.1^{\mathrm{b}}$ & $4.8 \pm 0.2^{\mathrm{c}}$ \\
\hline Ovulation (\%) & $88.4^{\mathrm{a}}$ & $62.1^{\mathrm{b}}$ & $85.7^{\mathrm{a}}$ & $86.6^{\mathrm{a}}$ & $54.2^{\mathrm{b}}$ \\
\hline
\end{tabular}

\footnotetext{
${ }^{\mathrm{a}-\mathrm{c}}$ Row means within a category with different superscript letters differ $(P \leq 0.05)$.

${ }^{1}$ Values are means $\pm \mathrm{SE}$.

${ }^{2}$ Pre-GnRH progesterone concentrations.
} 

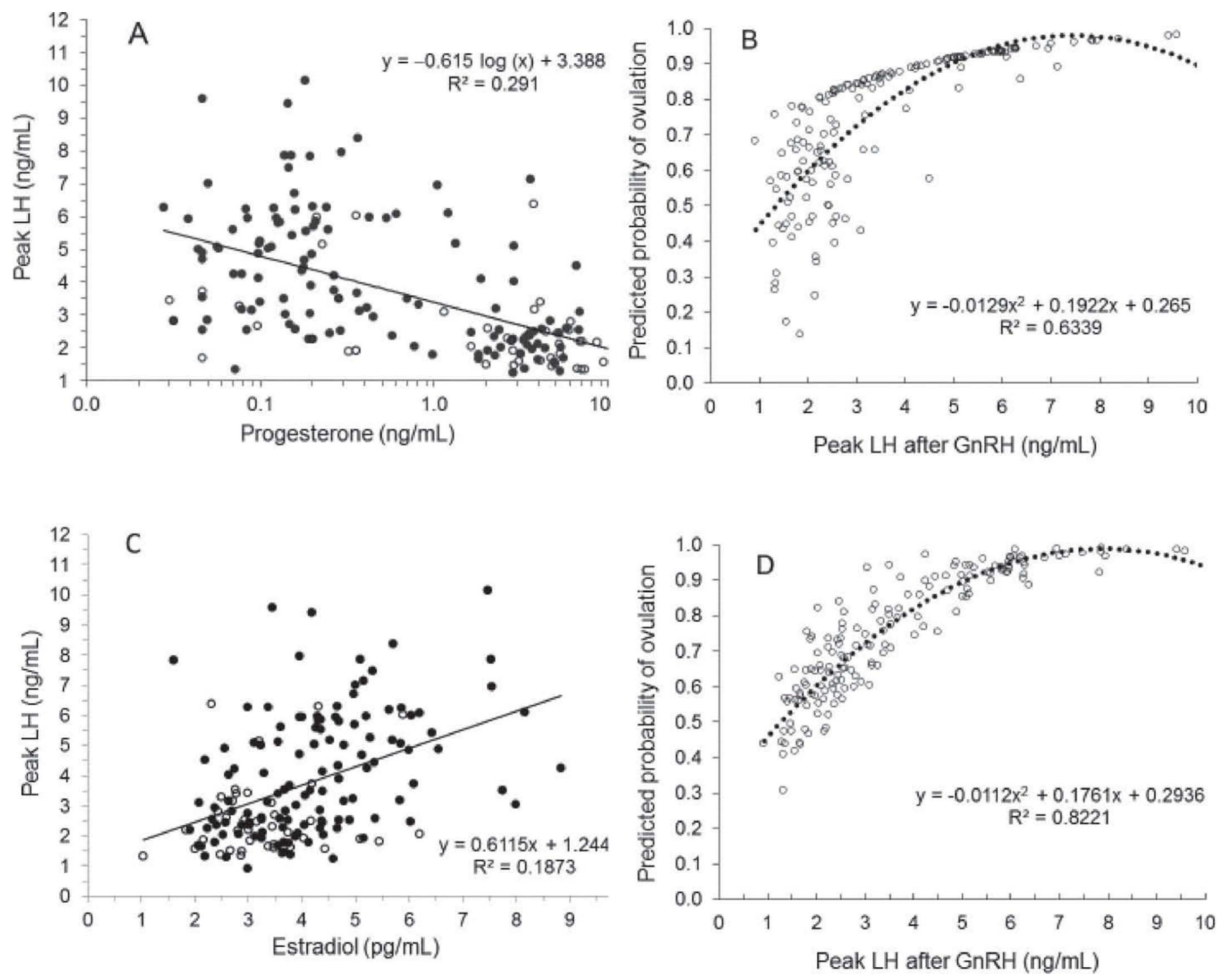

Figure 3. Relationship of least squares means peak LH concentrations during $6 \mathrm{~h}$ after $100 \mu \mathrm{g}$ of GnRH and concentrations of progesterone (panel A; log scale) or concentrations of estradiol (panel C) before each GnRH treatment in dairy cows. Cow means represented by the closed circles $(\mathrm{n}=122)$ ovulated or did not ovulate (open circles; $\mathrm{n}=41$ ) after $\mathrm{GnRH}$ treatment. Panels B and D illustrate the predicted probability of ovulation regressed on peak LH concentrations after $\mathrm{GnRH}$ after adjusting for concentrations of progesterone (panel B) or estradiol (panel D) before GnRH treatment in multilogistic regression models.

and pattern of GnRH-induced LH release in response to the GnRH treatments typical to a TAI program. In each 163 of $173 \mathrm{GnRH}$ treatments, an LH response curve was observed, peaking at approximately 1 to $2 \mathrm{~h}$ and decreasing to baseline at or near $6 \mathrm{~h}$ after $\mathrm{GnRH}$, consistent with previous reports (Lucy and Stevenson, 1986; Souza et al., 2009). Eliminated from the study were 10 of the $173 \mathrm{LH}$ profiles in which LH was released spontaneously before $\mathrm{GnRH}$ was administered.

The progesterone concentration before $\mathrm{GnRH}$ treatment inhibited, whereas estradiol stimulated subsequent
GnRH-induced LH release characteristics and significantly altered incidences of ovulation. Furthermore, the GnRH-induced LH profiles represented dose-dependent responses to both progesterone and estradiol. Concentrations of progesterone in the range of 0.53 to $2.41 \mathrm{ng} /$ $\mathrm{mL}$ inhibited GnRH-induced LH characteristics in dairy cows compared with those having concentrations $<0.45$ $\mathrm{ng} / \mathrm{mL}$. Only at greater concentrations of progesterone $(>2.66 \mathrm{ng} / \mathrm{mL})$, consistent with a likely functional mature CL, was incidence of ovulation compromised. The inhibitory concentrations of progesterone $(>0.53$ 
$\mathrm{ng} / \mathrm{mL}$ ), typical of cows in metestrus and diestrus, are consistent with the reported effects of a functional CL on LH release in dairy cattle (Giordano et al., 2012).

We observed less LH responsiveness of the pituitary gland to $\mathrm{GnRH}$ at greater concentrations of progesterone. Progesterone may directly inhibit LH release at the pituitary gland because receptors for progesterone are present in the bovine pituitary (Schoenemann et al., 1985). Furthermore, GnRH can regulate its own receptor with greater $\mathrm{GnRH}$ release by upregulating the $\mathrm{GnRH}$ receptor in the anterior pituitary (Nett et al., 2002). Therefore, progesterone inhibition of $\mathrm{GnRH}$ pulses may decrease the number of pituitary $\mathrm{GnRH}$ receptors and responsiveness of the pituitary to GnRH.
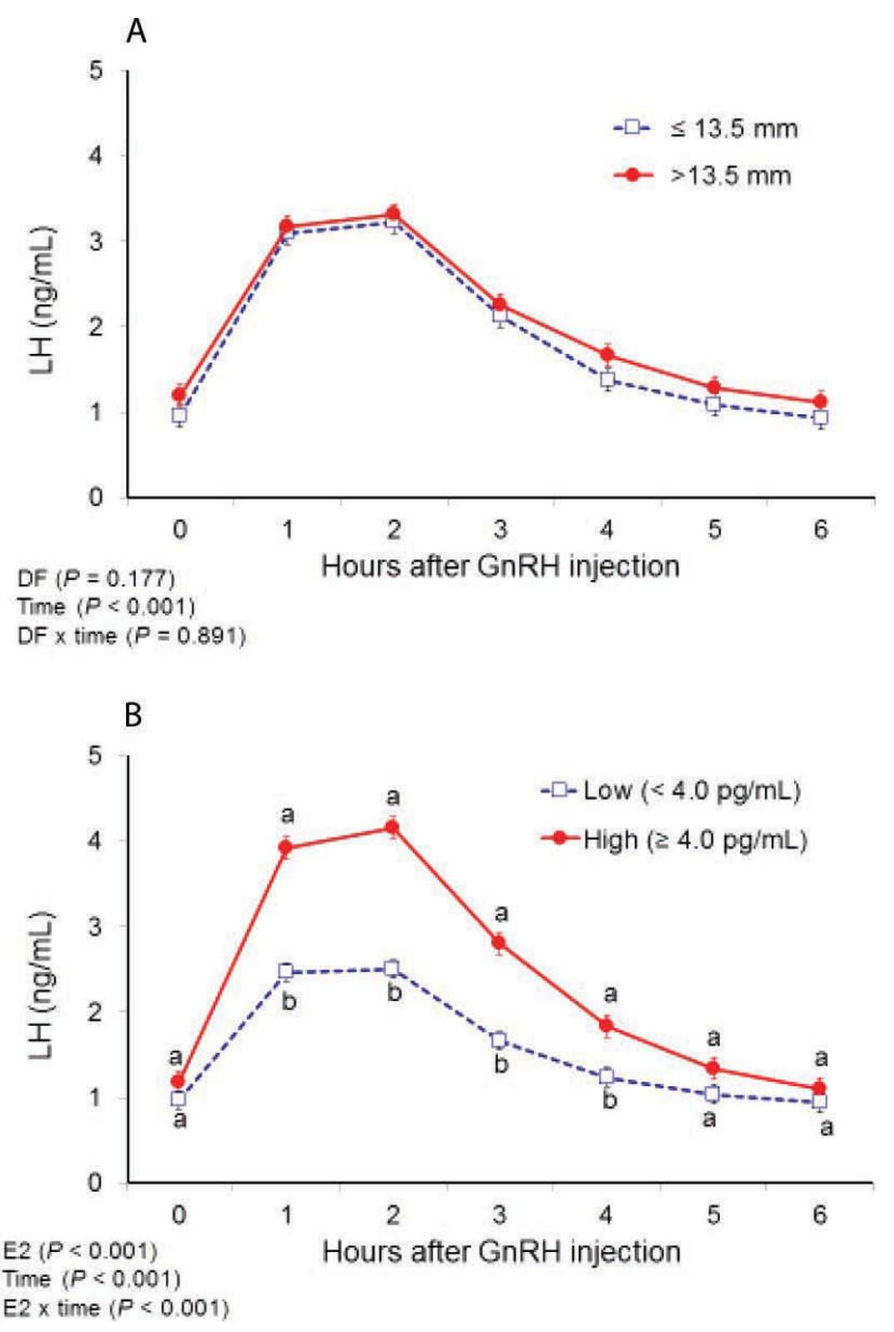

Figure 4. (A) Least squares means LH concentrations during 6 $\mathrm{h}$ after $100 \mu \mathrm{g}$ of $\mathrm{GnRH}$ based on dominant follicle (DF) diameter $(\leq 13.5 \mathrm{~mm} ; \mathrm{n}=83)$ or $>13.5 \mathrm{~mm}(\mathrm{n}=80)$. (B) Least squares means $\mathrm{LH}$ concentrations during $6 \mathrm{~h}$ after $100 \mu \mathrm{g}$ of $\mathrm{GnRH}$ for dairy cows having low $(\mathrm{n}=89)$ or high $(\mathrm{n}=74)$ concentrations of estradiol (E2) before GnRH treatment. Bars associated with each mean represent the standard errors. Color version available online.
Larger doses of GnRH $(200 \mu \mathrm{g})$, however, were capable of eliciting LH release in lactating dairy cows exposed to both high- or low-progesterone environments compared with a lesser dose (100 $\mu \mathrm{g}$; Giordano et al., 2012).

Ovulation was not compromised in cows having medium concentrations of progesterone (0.53 to 2.41 $\mathrm{ng} / \mathrm{mL}$ ) even though all of the LH characteristics were significantly suppressed compared with cows having the lowest progesterone concentrations $(<0.45 \mathrm{ng} / \mathrm{mL})$. This lack of ovulation reduction indicates that some threshold of LH concentration was reached to ensure that ovulation occurred despite differences in progesterone concentration between the low and medium progesterone categories and no differences in dominant follicle diameter.

Failure to ovulate was observed in dairy cows that had reduced LH concentrations in the face of progesterone varying from $<0.1$ to $10.7 \mathrm{ng} / \mathrm{mL}$. In a similar manner, ovulation failure occurred at reduced LH concentrations across concentrations of estradiol ranging from 1.0 to $8.8 \mathrm{pg} / \mathrm{mL}$. Even though 58 of 66 cows ovulated when progesterone was $<0.45 \mathrm{ng} / \mathrm{mL}$, regardless of estradiol concentration, 7 of 8 cows also ovulated when progesterone was $>0.45 \mathrm{ng} / \mathrm{mL}$. Limitations to inducing ovulation with $\mathrm{GnRH}$ in cows with functional CL, such as pregnant cows or virgin heifers, even in the presence of growing dominant follicles, may be related to decreased GnRH-induced LH release rather than the inability of follicles to ovulate (Giordano et al., 2012).

Presence of larger dominant follicles had little effect on GnRH-induced LH release, but more follicles ovulated when $>13.5 \mathrm{~mm}$ than at lesser diameters. In the absence of a CL or low concentrations of progesterone, presence of a larger follicle or greater estradiol did not significantly enhance concentrations of LH, but at similar concentrations of progesterone and mean LH, ovulation incidence tended to be greater when estradiol was $\geq 4.0 \mathrm{pg} / \mathrm{mL}$. Increase in estradiol secretion by the dominant follicle during the preovulatory period increases the sensitivity of the anterior pituitary to $\mathrm{GnRH}$ by upregulating $\mathrm{GnRH}$ receptor mRNA in gonadotrophs (Schoenemann et al., 1985). In addition, estradiol enhances hypothalamic GnRH secretion, eventually leading to the preovulatory $\mathrm{GnRH}$ surge, which subsequently initiates the LH surge. In contrast, in the presence of a functional CL, progesterone blocks the stimulatory effects of estradiol at the hypothalamus (Girmus and Wise, 1992; Baratta et al., 1994), which is consistent with the results of the present study.

Gonadal steroids are key regulators of gonadotropin secretion in cattle (Baratta et al., 1994; Nett et al., 2002). This regulation occurs at the hypothalamic level by altering frequency or amplitude of $\mathrm{GnRH}$ pulses as well as direct regulation of $\mathrm{GnRH}$ responsiveness in 
Table 2. Concentration of estradiol alters characteristics of LH concentration during $6 \mathrm{~h}$ after GnRH treatment and subsequent GnRH-induced ovulation in lactating dairy cows ${ }^{1}$

\begin{tabular}{|c|c|c|c|c|}
\hline \multirow[b]{2}{*}{ Item } & \multicolumn{2}{|c|}{ Follicle (mm) } & \multicolumn{2}{|c|}{ Estradiol $^{2}(\mathrm{pg} / \mathrm{mL})$} \\
\hline & $\leq 13.5$ & $>13.5$ & $<4.0$ & $\geq 4.0$ \\
\hline $\begin{array}{l}\text { Observations (no.) } \\
\text { Pre-GnRH LH (ng/mL) } \\
\text { Largest LH value }(\mathrm{ng} / \mathrm{mL}) \\
\text { Second largest LH value }(\mathrm{ng} / \mathrm{mL}) \\
\text { Area under the LH }(\mathrm{ng} \cdot \mathrm{h} / \mathrm{mL}) \\
\text { Mean LH }(\mathrm{ng} / \mathrm{mL}) \\
\text { Variance } \mathrm{LH} \\
\text { Time to LH peak }(\mathrm{h}) \\
\text { Follicle diameter }(\mathrm{mm}) \\
\text { Estradiol }(\mathrm{pg} / \mathrm{mL}) \\
\text { Progesterone }(\mathrm{ng} / \mathrm{mL}) \\
\text { Ovulation }(\%)\end{array}$ & $\begin{aligned} & 83 \\
& 1.0 \pm 0.06^{\mathrm{A}} \\
& 3.4 \pm 0.2^{\mathrm{a}} \\
& 2.8 \pm 0.2^{\mathrm{a}} \\
& 11.5 \pm 0.8^{\mathrm{a}} \\
& 1.7 \pm 0.09^{\mathrm{a}} \\
& 1.6 \pm 0.3^{\mathrm{a}} \\
& 1.4 \pm 0.06^{\mathrm{a}} \\
& 11.4 \pm 0.2^{\mathrm{a}} \\
& 3.9 \pm 0.1^{\mathrm{A}} \\
& 2.0 \pm 0.3^{\mathrm{a}} \\
& 66.0^{\mathrm{a}}\end{aligned}$ & $\begin{aligned} & 80 \\
& 1.2 \pm 0.1^{\mathrm{B}} \\
& 3.7 \pm 0.2^{\mathrm{a}} \\
& 3.0 \pm 0.2^{\mathrm{a}} \\
& 12.8 \pm 0.7^{\mathrm{a}} \\
& 1.9 \pm 0.08^{\mathrm{a}} \\
& 1.6 \pm 0.2^{\mathrm{a}} \\
& 1.6 \pm 0.07^{\mathrm{b}} \\
& 16.0 \pm 0.3^{\mathrm{b}} \\
& 4.3 \pm 0.2^{\mathrm{B}} \\
& 1.7 \pm 0.3^{\mathrm{a}} \\
& 82.8^{\mathrm{b}}\end{aligned}$ & $\begin{aligned} & 89 \\
& 1.0 \pm 0.09^{\mathrm{A}} \\
& 2.8 \pm 0.2^{\mathrm{a}} \\
& 2.2 \pm 0.2^{\mathrm{a}} \\
& 10.5 \pm 0.6^{\mathrm{a}} \\
& 1.5 \pm 0.07^{\mathrm{a}} \\
& 0.8 \pm 0.2^{\mathrm{a}} \\
& 1.4 \pm 0.07^{\mathrm{a}} \\
& 13.3 \pm 0.4^{\mathrm{A}} \\
& 3.1 \pm 0.07^{\mathrm{a}} \\
& 2.8 \pm 0.3^{\mathrm{a}} \\
& 63.5^{\mathrm{a}}\end{aligned}$ & $\begin{aligned} & 74 \\
& 1.2 \pm 0.09^{\mathrm{B}} \\
& 4.4 \pm 0.2^{\mathrm{b}} \\
& 3.7 \pm 0.2^{\mathrm{b}} \\
& 14.1 \pm 0.8^{\mathrm{b}} \\
& 2.2 \pm 0.09^{\mathrm{b}} \\
& 2.4 \pm 0.3^{\mathrm{b}} \\
& 1.6 \pm 0.06^{\mathrm{a}} \\
& 14.2 \pm 0.4^{\mathrm{B}} \\
& 5.2 \pm 0.1^{\mathrm{b}} \\
& 0.9 \pm 0.1^{\mathrm{b}} \\
& 86.9^{\mathrm{b}}\end{aligned}$ \\
\hline
\end{tabular}

the anterior pituitary (Goodman and Karsch, 1980; Schoenemann et al., 1985; Nett et al., 2002). Our findings are consistent with other experimental evidence that support the negative and positive feedback roles of progesterone and estradiol, respectively, on pituitary function. At 2 concentration ranges of progesterone $(<0.45$ vs. $>0.53 \mathrm{ng} / \mathrm{mL})$, greater concentrations of estradiol ( $<4$ vs. $\geq 4 \mathrm{pg} / \mathrm{mL}$ ) were able to increase $\mathrm{LH}$ release in response to GnRH (Figure 5). The previous response to GnRH confirms the notion that progesterone seems to block the stimulatory effects of estradiol at the anterior pituitary (Baratta et al., 1994; Rispoli and Nett, 2005) beyond what has been observed to occur at the level of the hypothalamus (Schoenemann et al., 1985; Girmus and Wise, 1992). Alternatively, the acute effect of GnRH-induced LH release was smaller in cows with high rather than low concentrations of progesterone before $\mathrm{GnRH}$ treatment, suggesting that the additive effect of low progesterone and high estradiol on LH concentrations might be dependent on stage of the estrous cycle (chronic or sustained steroid milieu) before GnRH treatment, which was not explored in the current study.

Although GnRH-induced ovulation starting the Ovsynch program is related to subsequent TAI pregnancy risk (Pursley et al., 1997; Stevenson et al., 2012; Bisinotto et al., 2014), pregnancy risk also is related to the presence or absence of a CL at the start of the TAI program. It was demonstrated that pregnancy risk of cows starting Ovsynch without a CL, but treated with 1 or 2 progesterone inserts, was not different from that of diestrous cows with a CL; both treatments had greater P/AI than controls without a CL (Stevenson et al., 2008; Bisinotto et al., 2013, 2015). Ovulation response to $\mathrm{GnRH}$ can be decreased in cows receiving an intravaginal progesterone insert (Galvão et al., 2004; Stevenson et al., 2008) because progesterone is absorbed very quickly such that circulating progesterone concentrations are elevated within 15 min after treatment with a progesterone insert (Cerri et al., 2009). In contrast, others failed to observe a reduction in ovulation to $\mathrm{GnRH}$ in cows treated simultaneously

Table 3. Mean $( \pm \mathrm{SE}) \mathrm{LH}$ concentration during $6 \mathrm{~h}$ after $\mathrm{GnRH}$ and incidence of ovulation in dairy cows based on presence of a corpus luteum (CL) and size of the dominant follicle

\begin{tabular}{lccc}
\hline Item $^{1}$ & $\mathrm{n}$ & $\mathrm{LH}^{2}(\mathrm{ng} / \mathrm{mL})$ & Ovulation $^{3}(\%)$ \\
\hline No CL & & & \\
Dominant follicle $\leq 13.5 \mathrm{~mm}$ & 36 & $2.2 \pm 0.10$ & 80.7 \\
Dominant follicle $>13.5 \mathrm{~mm}$ & 41 & $2.1 \pm 0.08$ & \\
CL present & 47 & $1.3 \pm 0.08$ & 52.6 \\
Dominant follicle $\leq 13.5 \mathrm{~mm}$ & 39 & $1.6 \pm 0.10$ & 70.0 \\
Dominant follicle $>13.5 \mathrm{~mm}$ & &
\end{tabular}

${ }^{1}$ Ovarian structures at the time of $\mathrm{GnRH}$ treatment.

${ }^{2}$ Effect of dominant follicle (DF; $\left.P=0.388\right)$; effect of CL $(P<0.001)$; DF $\times$ CL interaction $(P=0.091)$.

${ }^{3}$ Effect of DF $(P=0.022)$; effect of CL $(P=0.001)$; DF $\times$ CL interaction $(P=0.403)$. 


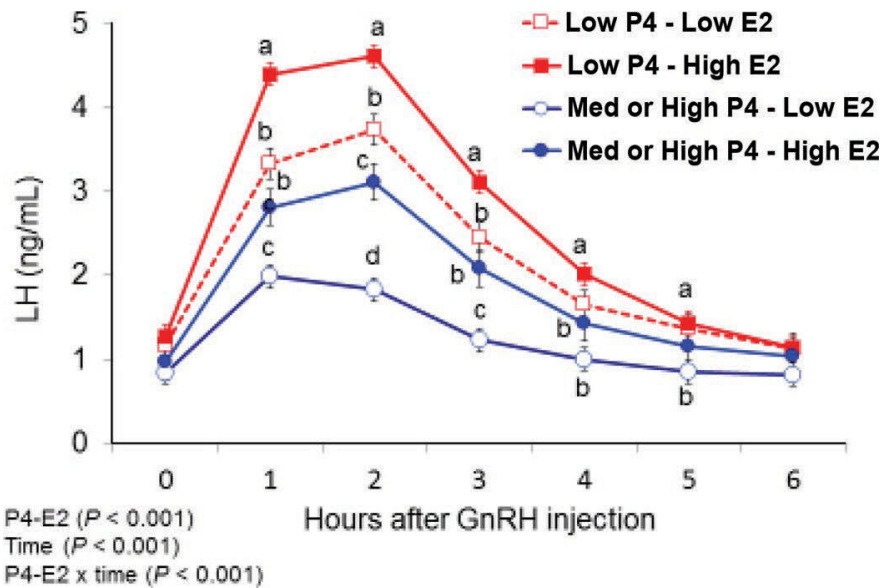

Figure 5. Least squares means LH concentrations during $6 \mathrm{~h}$ after $100 \mu \mathrm{g}$ of $\mathrm{GnRH}$ for dairy cows having various combinations of progesterone and estradiol (at the time of GnRH treatment): (1) low $(<0.45$ $\mathrm{ng} / \mathrm{mL}$ ) progesterone $(\mathrm{P} 4)$ and low $(<4.0 \mathrm{pg} / \mathrm{mL})$ estradiol $(\mathrm{E} 2 ; \mathrm{n}$ $=31)$; (2) low P4 and high E2 $(\geq 4.0 \mathrm{pg} / \mathrm{mL} ; \mathrm{n}=52) ;(3)$ medium to high P4 (0.53 to $10.7 \mathrm{ng} / \mathrm{mL})$ and low E2 $(\mathrm{n}=58)$; and medium to high P4 and high E2 $(\mathrm{n}=22)$. Means with different letters $(\mathrm{a}-\mathrm{d})$ within hour differ $(P \leq 0.05)$; bars associated with each mean represent the standard errors. Color version available online.

with 1 (Bisinotto et al., 2010; Bilby et al., 2013; Chebel et al., 2013) or 2 progesterone inserts (Denicol et al., 2012; Bisinotto et al., 2013; Bisinotto et al., 2015).

The steroid milieu consisting of both estradiol and progesterone at the time of $\mathrm{GnRH}$ treatments in TAI programs is critical to subsequent $\mathrm{LH}$ responses and

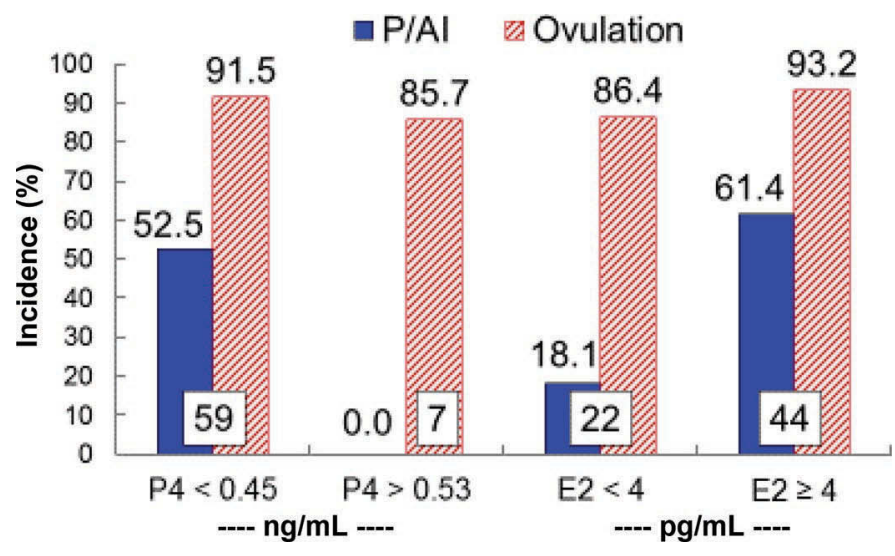

Figure 6. Incidence of ovulation and pregnancy per AI (P/AI) for 66 lactating dairy cows on the basis of progesterone $[(\mathrm{P} 4)$ low $=<0.45$ $(\mathrm{n}=59)$ and high $=>0.53 \mathrm{ng} / \mathrm{mL}(\mathrm{n}=7)]$ and estradiol $[(\mathrm{E} 2)$ low $=$ $<4.0(\mathrm{n}=22)$ and high $=\geq 4.0 \mathrm{pg} / \mathrm{mL}(\mathrm{n}=44)]$ concentrations before GnRH treatment at 56 or $72 \mathrm{~h}$ after $\mathrm{PGF}_{2 \alpha}$ (timed AI at $72 \mathrm{~h}$ ). Time of GnRH treatment after $\mathrm{PGF}_{2 \alpha}$ had no effect on incidence of ovulation or $\mathrm{P} / \mathrm{AI}$. Neither progesterone nor estradiol affected ovulation incidence. Progesterone at the greater concentration decreased $(P=0.02)$ $\mathrm{P} / \mathrm{AI}$, whereas estradiol at the greater concentration increased $(P=$ 0.05) P/AI. Values shown just above the horizontal axis within bars are the number of cows per pair of bars. Color version available online. incidence of $\mathrm{GnRH}$-induced ovulation to maximize pregnancy outcomes after a fixed time. Limitations to pregnancy outcomes after TAI programs include the responsiveness of cows to hormonal manipulations of follicular growth, ovulation, and regression of the CL. Synchronization risks in studies are often evaluated to assess the success of both luteolysis and subsequent ovulation associated with a fixed-time AI. In dairy cows, those with a CL (diestrus) have greater pregnancy risk when starting the Ovsynch program compared with those without a CL (Stevenson et al., 2008) as well as those with a greater incidence of ovulation in response to the GnRH treatment that initiates the TAI program (Pursley et al., 1997; Stevenson et al., 2012; Bisinotto et al., 2015).

Despite limited numbers of cows in the present experiment for assessing pregnancy outcomes, $\mathrm{P} / \mathrm{AI}$ was influenced significantly by concentrations of progesterone and estradiol. More cows conceived when progesterone concentration before $\mathrm{GnRH}$ treatment was $<0.45 \mathrm{ng} / \mathrm{mL}$ than $>0.53 \mathrm{ng} / \mathrm{mL}$, despite similar ovulatory responses, suggesting that sufficient LH release occurred to stimulate ovulation, but elevated progesterone concentration at TAI was a limiting $\mathrm{P} / \mathrm{AI}$. In a like manner, when estradiol was $\geq 4 \mathrm{pg} / \mathrm{mL}$, more cows conceived than when estradiol was $<4 \mathrm{pg} / \mathrm{mL}$, despite similar ovulatory responses to LH. Because no evidence was detected for an interaction of the 2 steroids on $\mathrm{P} /$ AI, it seems that a threshold LH response was sufficient to cause ovulation, but pregnancy outcome was either facilitated or inhibited by estradiol and progesterone, respectively.

In a recent review of studies (Wiltbank et al., 2014) using GnRH to induce ovulation, it was concluded that circulating concentrations of progesterone $>0.3$ to 0.5 $\mathrm{ng} / \mathrm{mL}$ at the time of $\mathrm{AI}$ were detrimental to fertility in dairy cattle. Inadequate luteolysis can result in an elevation in circulating progesterone near AI and a reduction in fertility as demonstrated in several reports (see Wiltbank et al., 2014). Alternatively, elevated progesterone may alter sperm or oocyte transport by altering uterine or oviductal contractility (Hawk, 1987) and thus reduce fertilization risk (Hunter, 2005). In addition, supplementing progesterone to in vitro fertilization medium reduced blastocyst rate (Silva and Knight, 2000), suggesting possible effects of progesterone during in vitro fertilization on subsequent embryo development.

Increased P/AI in other studies (Hillegass et al., 2008; Santos et al., 2010; Stevenson and Phatak, 2010) were observed consistently in which cows receiving a TAI were in estrus, had elevated concentrations of estradiol, or both. Results from the present study demonstrated that cows with greater concentrations of estradiol also 
had larger LH peak concentrations after GnRH and greater incidence of ovulation. Fertility of dairy cows also is associated positively with the diameter of the ovulatory follicle (Vasconcelos et al., 1999) and concentrations of estradiol in plasma (Lopes et al., 2007).

\section{CONCLUSIONS}

Increased concentrations of progesterone, consistent with presence of a functional CL, inhibited GnRHinduced LH release, limited ovulation, and reduced $\mathrm{P} /$ AI of dairy cows in a TAI program. Independent of progesterone, greater ovulation incidence was observed in cows with greater concentrations of both $\mathrm{LH}$ and estradiol. When both steroids were considered in cows before TAI, incidences of ovulation were increased at the same low concentrations of progesterone, but at similar GnRH-induced LH peak concentrations. Pregnancy outcomes for TAI programs are highly dependent on low concentrations of progesterone at TAI, but in addition, at greater concentrations of estradiol and similar LH release, P/AI and ovulation incidence were increased in cows enrolled in the current study. Coupled with results cited herein, $\mathrm{P} / \mathrm{AI}$ subsequent to TAI requires increased concentrations of estradiol to facilitate more than just greater LH release to maximize ovulation. Furthermore, we conclude that when progesterone concentration exceeded $0.5 \mathrm{ng} / \mathrm{mL}$ at the time of GnRH treatment, subsequent LH concentrations and ovulation were suppressed during the periovulatory-AI period. At that same concentration of progesterone or when concentrations of estradiol were $\geq 4 \mathrm{pg} / \mathrm{mL}$, TAI pregnancy outcomes were improved in the face of similar incidences of ovulation, suggesting greater progesterone or lesser estradiol at the time of AI may inhibit pregnancy establishment by other mechanisms.

\section{ACKNOWLEDGMENTS}

The authors gratefully acknowledge donations of Factrel and Lutalyse from Pfizer Animal Health; care, feeding, and milking of cows by Mike Scheffel and full-time employees of the KSU Dairy Teaching and Research Center; laboratory assistance by Colleen Hill and Duane Keisler; and veterinary care of cows by Shelie Laflin. This study was funded by Select Sires (Plain City, OH) and Hatch-Multistate NC 1201 "Methods to Increase Reproductive Efficiency in Cattle."

\section{REFERENCES}

Atkins, J. A., D. C. Busch, J. F. Bader, D. H. Keisler, D. J. Patterson, M. C. Lucy, and M. F. Smith. 2008. Gonadotropin-releasing hormone induced ovulation and luteinizing hormone release in beef heifers: Effect of day of the cycle. J. Anim. Sci. 86:83-93.

Baratta, M., F. Grassell, and C. Tamanini. 1994. Effects of gonadal steroids on tonic luteinizing hormone ( $\mathrm{LH}$ ) release and luteinizing hormone-releasing hormone-induced LH release from bovine pituitary cells cultured in vitro. Biol. Reprod. 50:1320-1327.

Bilby, T. R., R. G. Bruno, K. J. Lager, R. C. Chebel, J. G. Moraes, P. M. Fricke, G. Lopes Jr., J. O. Giordano, J. E. Santos, F. S. Lima, J. S. Stevenson, and S. L. Pulley. 2013. Supplemental progesterone and timing of resynchronization on pregnancy outcomes in lactating dairy cows. J. Dairy Sci. 96:7032-7042.

Bisinotto, R. S., L. O. Castro, M. B. Pansani, C. D. Narciso, N. Martinez, L. D. Sinedino, T. L. C. Pinto, M. S. Van de Burgwal, H. M. Bosman, R. S. Surjus, W. W. Thatcher, and J. E. P. Santos. 2015. Progesterone supplementation to lactating dairy cows without a corpus luteum at initiation of the Ovsynch protocol. J. Dairy Sci. 98:2515-2528.

Bisinotto, R. S., E. S. Ribeiro, F. S. Lima, N. Martinez, L. F. Greco, L. F. S. P. Barbosa, P. P. Bueno, L. F. S. Scagion, W. W. Thatcher, and J. E. P. Santos. 2013. Targeted progesterone supplementation improves fertility in lactating dairy cows without a corpus luteum at the initiation of the timed artificial insemination protocol. J Dairy Sci. 96:2214-2225.

Bisinotto, R. S., E. S. Ribeiro, L. T. Martins, R. S. Marsola, L. F. Greco, M. G. Favoreto, C. A. Risco, W. W. Thatcher, and J. E. Santos. 2010. Effect of interval between induction of ovulation and artificial insemination (AI) and supplemental progesterone for resynchronization on fertility of dairy cows subjected to a 5 -d timed AI program. J. Dairy Sci. 93:5798-5808.

Bisinotto, R. S., E. S. Ribeiro, and J. E. P. Santos. 2014. Synchronisation of ovulation for management of reproduction in dairy cows. Animal 8(Suppl. 1):151-159.

Cerri, R. L., H. M. Rutigliano, R. G. Bruno, and J. E. Santos. 2009. Progesterone concentration, follicular development and induction of cyclicity in dairy cows receiving intravaginal progesterone inserts. Anim. Reprod. Sci. 110:56-70.

Chebel, R. C., A. A. Scanavez, P. R. Silva, J. G. Moraes, L. G. Mendonça, and G. Lopes Jr.. 2013. Evaluation of presynchronized resynchronization protocols for lactating dairy cows. J. Dairy Sci. 96:1009-1020.

Denicol, A. C., G. Lopes Jr., L. G. Mendonça, F. A. Rivera, F. Guagnini, R. V. Perez, J. R. Lima, R. G. Bruno, J. E. Santos, and R. C. Chebel. 2012. Low progesterone concentration during the development of the first follicular wave reduces pregnancy per insemination of lactating dairy cows. J. Dairy Sci. 95:1794-1806.

Galvão, K. N., J. E. P. Santos, S. O. Juchem, R. L. A. Cerri, A. C. Coscioni, and M. Villaseñor. 2004. Effect of addition of a progesterone intravaginal insert to a timed insemination protocol using estradiol cypionate on ovulation rate, pregnancy rate, and late embryonic loss in lactating dairy cows. J. Anim. Sci. 82:3508-3517.

Giordano, J. O., P. M. Fricke, J. N. Guenther, G. Lopes Jr., M. M. Herlihy, A. B. Nascimento, and M. C. Wiltbank. 2012. Effect of progesterone on magnitude of the luteinizing hormone surge induced by 2 different doses of gonadotropin-releasing hormone in lactating dairy cows. J. Dairy Sci. 95:3781-3793.

Girmus, R. L., and M. E. Wise. 1992. Progesterone directly inhibits pituitary luteinizing hormone secretion in an estradiol-dependent manner. Biol. Reprod. 46:710-714.

Goodman, R. L., and F. J. Karsch. 1980. Pulsatile secretion of luteinizing hormone: Differential suppression by ovarian steroids. Endocrinology 107:1286-1290.

Hawk, H. W. 1987. Transport and fate of spermatozoa after insemination of cattle. J. Dairy Sci. 70:1487-1503.

Hillegass, J., F. S. Lima, M. F. Sa Filho, and J. E. P. Santos. 2008. Effect of time of artificial insemination and supplemental estradiol on reproduction of lactating dairy cows. J. Dairy Sci. 91:4226-4237.

Hunter, R. H. F. 2005. The fallopian tubes in domestic mammals: How vital is their physiological activity? Reprod. Nutr. Dev. 45:281-290.

Lopes, A. S., S. T. Butler, R. O. Gilbert, and W. R. Butler. 2007. Relationship of pre-ovulatory follicle size, estradiol concentrations 
and season to pregnancy outcome in dairy cows. Anim. Reprod. Sci. 99:34-43.

López-Gatius, F., M. López-Béjar, M. Fenech, and R. H. Hunter. 2005. Ovulation failure and double ovulation in dairy cattle: Risk factors and effects. Theriogenology 63:1298-1307.

Lucy, M. C., and J. S. Stevenson. 1986. Gonadotropin-releasing hormone at estrus: Luteinizing hormone, estradiol, and progesterone during the periestrual and postinsemination periods in dairy cattle. Biol. Reprod. 35:300-311.

Moreira, F., R. L. de la Sota, T. Diaz, and W. W. Thatcher. 2000. Effect of day of the estrous cycle at the initiation of a timed artificial insemination protocol on reproductive responses in dairy heifers. J. Anim. Sci. 78:1568-1576.

NRC. 2001. Nutrient Requirements of Dairy Cattle. 7th rev. ed., Natl. Acad. Sci., Washington, DC.

Nett, T. M., A. M. Turzillo, M. Baratta, and L. A. Rispoli. 2002. Pituitary effects of steroid hormones on secretion of follicle-stimulating hormone and luteinizing hormone. Domest. Anim. Endocrinol. $23: 33-42$

Pulley, S. L., D. H. Keisler, and J. S. Stevenson. 2015. Concentrations of luteinizing hormone and ovulatory responses in dairy cows before timed artificial insemination. J. Dairy Sci. 98:6188-6201.

Pursley, J. R., M. R. Kosorok, and M. C. Wiltbank. 1997. Reproductive management of lactating dairy cows using synchronization of ovulation. J. Dairy Sci. 80:301-306.

Pursley, J. R., M. O. Mee, and M. C. Wiltbank. 1995. Synchronization of ovulation in dairy cows using $\mathrm{PGF}_{2 \alpha}$ and $\mathrm{GnRH}$. Theriogenology 44:915-923.

Ribeiro, E. S., A. P. A. Monteiro, F. S. Lima, H. Ayres, R. S. Bisinotto, M. Favoreto, L. F. Greco, R. S. Marsola, W. W. Thatcher, and J. E. Santos. 2012. Effects of presynchronization and length of proestrus on fertility of grazing dairy cows subjected to a 5-day timed artificial insemination protocol. J. Dairy Sci. 95:2513-2522.

Rispoli, L. A., and T. M. Nett. 2005. Pituitary gonadotropin-releasing hormone $(\mathrm{GnRH})$ receptor: Structure, distribution and regulation of expression. Anim. Reprod. Sci. 88:57-74.

Santos, J. E. P., C. D. Narciso, F. Rivera, W. W. Thatcher, and R. C. Chebel. 2010. Effect of reducing the period of follicle dominance in a TAI protocol on reproduction of dairy cows. J. Dairy Sci. 93:2976-2988.

Schoenemann, H. M., W. D. Humphrey, M. E. Crowder, T. M. Nett, and J. J. Reeves. 1985. Pituitary luteinizing hormone-releasing hormone receptors in ovariectomized cows after challenge with ovarian steroids. Biol. Reprod. 32:574-583.

Silva, C. C., and P. G. Knight. 2000. Effects of androgens, progesterone and their antagonists on the developmental competence of in vitro matured bovine oocytes. J. Reprod. Fertil. 119:261-269.

Souza, A. H., A. P. Cunha, E. P. B. Silva, A. Gumen, H. Ayres, and M. C. Wiltbank. 2009. Comparison of gonadorelin products in lactating dairy cows: Efficacy based on induced of ovulation of an accessory follicle and circulating luteinizing hormone profiles. Theriogenology 72:271-279.

Stevenson, J. S., and A. P. Phatak. 2010. Rates of luteolysis and pregnancy in dairy cows after treatment with cloprostenol or dinoprost. Theriogenology 73:1127-1138.

Stevenson, J. S., and S. L. Pulley. 2012. Pregnancy per artificial insemination after presynchronizing estrous cycles with the Presynch-10 protocol or prostaglandin $\mathrm{F}_{2 \alpha}$ injection followed by gonadotropinreleasing hormone before Ovsynch-56 in 4 dairy herds of lactating dairy cows. J. Dairy Sci. 95:6513-6522.

Stevenson, J. S., S. L. Pulley, and H. I. Mellieon Jr.. 2012. Prostaglandin $\mathrm{F}_{2 \alpha}$ and gonadotropin-releasing hormone administration improve progesterone status, luteal number, and proportion of ovular and anovular dairy cows with corpora lutea before a timed artificial insemination program. J. Dairy Sci. 95:1831-1844.

Stevenson, J. S., D. E. Tenhouse, R. L. Krisher, G. C. Lamb, J. E. Larson, C. R. Dahlen, J. R. Pursley, N. M. Bello, P. M. Fricke, M. C. Wiltbank, D. J. Brusveen, M. Burkhart, R. S. Youngquist, and H. A. Garverick. 2008. Detection of anovulation by heatmount detectors and transrectal ultrasonography before treatment with progesterone in a timed insemination protocol. J. Dairy Sci. 91:2901-2915.

Vasconcelos, J. L. M., R. W. Silcox, G. J. Rosa, J. R. Pursley, and M. C. Wiltbank. 1999. Synchronization rate, size of the ovulatory follicle, and pregnancy rate after synchronization of ovulation beginning on different days of the estrous cycle in lactating dairy cows. Theriogenology 52:1067-1078.

Wiltbank, M. C. A. H. Souza, P. D. Carvalho, A. P. Cunha, J. O Giordano, P. M. Fricke, G. M. Baez, and M. G. Diskin. 2014. Physiological and practical effects of progesterone on reproduction in dairy cattle. Animal 8(Suppl. 1):70-81. 